\title{
Peril in the market-classification and dosage of species used as anti-diabetics in Lima, Peru
}

\author{
Rainer W Bussmann ${ }^{1 *}$, Narel Paniagua-Zambrana², Marinoli Rivas Chamorro ${ }^{3}$, Natalia Molina Moreira ${ }^{4}$
} María Luisa del Rosario Cuadros Negri ${ }^{5}$ and Jose Olivera ${ }^{6}$

\begin{abstract}
Background: Peru is what Peruvian anthropologist Lupe Camino calls the "health axis" of the old Central Andean culture area stretching from Ecuador to Bolivia. In particular in the North of the country the traditional use of medicinal dates back as far as the first millennium B.C. Both healers, and the wider population, often buy their medicinal plants in local markets, but there is very little comparative information available about which plants are sold under which vernacular name at any given time, for which indication, and which dosage information and information about side effects is given by vendors. For this study we used two traditionally used species groups "Hercampuri" Gentianella spec. (Gentianaceae) and "Pasuchaca" Geranium spec. (Geraniaceae.), found in the Mercado Aviación in Lima, as small, clearly circumscribed plant group frequently used to treat symptoms of diabetes as a test case to study the taxonomy, indications, dosage, indicated side effects, and additional species used as admixtures and hypothesized that: 1 . A wide variety of different species is sold under the same common name, and often several common names exist for one species. 2. There is no consistency in the dosage, or a relationship between dosage and species marketed under one name. 3. However, there is consistency in the knowledge about usage and side effects.

Methods: Surveys focusing on medicinal plants sold and their properties were conducted at the Mercado Aviación in Lima in December 2012. Vouchers of all specimens were deposited th the National Herbarium of Peru.

Results and conclusions: Our surveys in Mercado Aviación in Lima yielded four species of Gentianella, two of Geranium, and three additional species from three genera used as common additives that were sold as anti-diabetic. These results indicate that even in case of only a few plant species, used for a very clearly circumscribed application, patients run a considerable risk when purchasing their remedies in the market. The possible side effects in this case are the more serious because diabetes has to be treated long term, and as such the patients are ingesting possible toxic remedies over a long period of time. Much more control, and a much more stringent identification of the material sold in public markets, and entering the global supply chain via internet sales, would be needed.
\end{abstract}

Keywords: Medicinal plants, Taxonomy, Systematics, Falsification, Efficacy, Gentianella, Geranium, Gentianaceae, Geraniaceae, Andes

\footnotetext{
* Correspondence: rainer.bussmann@mobot.org

${ }^{1}$ William L. Brown Center, Missouri Botanical Garden, PO Box 299, Saint Louis, MO 63166-0299, USA

Full list of author information is available at the end of the article
} 


\section{Resumen}

Antecedentes: El Perú es lo que el antropólogo peruano Lupe Camino llama el "eje de la salud" de la vieja zona cultural andina central que se extiende desde Ecuador hasta Bolivia. En particular en el norte del país el uso tradicional de las fechas medicinales remonta hasta el primer milenio aC. Tanto los curanderos, como la población general de frecuencia compran sus plantas medicinales en los mercados locales. Hay poca información comparativa sobre cual plantas se venden bajo el mismo nombre vernacular, para que indicación, y que información de dosificación e información sobre los efectos secundarios proveen los vendedores. Para este estudio utilizamos dos grupos de espacies tradicionalmente usadas, "Hercampuri" Gentianella spec. (Gentianaceae) y "Pasuchaca" Geranium spec. (Geraniaceae.), vendidos en el Mercado Aviación en Lima, como un grupo pequeño de planta claramente circunscrito y utilizado con frecuencia para tratar los síntomas de la diabetes, como un caso de prueba para estudiar la taxonomía, los indicaciones, la dosificación, los efectos secundarios indicados y otras especies usados como aditivos bajo los hipótesis de que: 1. Una amplia variedad de especies diferentes se vende bajo el mismo nombre común, y a menudo existen varios nombres comunes para una especie. 2. No hay consistencia en la dosis, o una relación entre dosis y especies comercializadas bajo un mismo nombre. 2. Sin embargo, hay consistencia en el conocimiento en uso y los efectos lado.

Métodos: Las encuestas sobre las plantas medicinales vendidas y sus propiedades fueron realizadas en el Mercado Aviación en Lima en Diciembre de 2012. Muestras de todos los especímenes fueron depositados en el Herbario Nacional del Perú.

Resultados y Conclusiones: Nuestros estudios en Mercado Aviación en Lima encontraron cuatro especies de Gentianella, dos de Geranium, y tres especies de tres géneros usados como aditivos que fueron vendidos como antidiabético. Los resultados indican que, incluso en caso de sólo unas pocas especies de plantas utilizadas para una aplicación muy claramente delimitada, los pacientes corren un alto riesgo en la compra de sus remedios en el mercado. Los efectos secundarios posibles en este caso pueden ser más serio ya que la diabetes tiene que ser tratado a largo plazo, y como tal, los pacientes ingieren posibles remedios tóxicos durante un largo período de tiempo. Mucho más control y una identificación mucho más estricta del material vendido en los mercados públicos, y entrando en la cadena de suministro global a través de las ventas por Internet, sería necesario.

Palabras claves: Plantas medicinales, Taxonomía, Sistematica, Falsificación, Eficacia, Gentianella, Geranium, Gentianaceae, Geraniaceae, Andes

\section{Background}

Northern Peru is what Peruvian anthropologist Lupe Camino calls the "health axis" of the old Central Andean culture area stretching from Ecuador to Bolivia [1]. In particular in the North of the country the traditional use of medicinal dates back as far as the first millennium B.C. (north coastal Cupisnique culture) or at least to the Moche period (100-800 AD), with healing scenes and healers frequently depicted in ceramics [2]. The extraordinary diversity of plant use in the region has always attracted scientific study. Early ethno botanically oriented studies focused mainly on the famous "magical" and "mind altering" flora of Peru. The first study on "cimora" -another vernacular name for the San Pedro cactus (Echinopsis pachanoi) dates back to the 1940's [3]. The first detailed study on a hallucinogen in Peru focused also on San Pedro, and Tree Datura (Brugmansia spp.) [4-8]. Coca (Erythroxylum coca) also attracted early scientific attention [9-13], as did the Amazonian Ayahuasca (Banisteriopsis caapi) [14-16]. Chiappe et. al [17] were the first to attempt an overview on the use of hallucinogens in shamanistic practices in Peru. General ethno botanical studies in Peru and Bolivia focused mostly on Quechua herbalism of the Cusco area [18-22], the border region of Peru and Bolivia around Lake Titicaca [23-26] and the Amazon [27-29]. Northern Peru, and especially its large medicinal plant markets, was studied more recently [30-38].

Both healers, and the wider population, often buy their medicinal plants in local markets. Information on the composition of the market flora, the origin of the plant material, and the quantities of plant material sold exists to some extent [37,39-41], and some studies focus on the interface between traditional and allopathic medicine [42,43]. Peru occupies a middle rank (125 of 223 countries surveyed) in diabetes prevalence (5-6\% of the population) [44], and the allopathic concept of diabetes is well known. Previous studies $[33,34,42,43]$ indicate that patients regularly receive their diagnosis from allopathic doctors, and then go to the markets to buy traditional remedies. Vendors also followed the allopathic concept. Initial bioassays indicate that at least for antibacterial applications the efficacy of parts of the medicinal flora can be proven [45-52], and preliminary data on plant toxicity exist [53]. However, there is very little comparative information available about which plants are 
sold under which vernacular name at any given time, for which indication, and which dosage information, and what kind of information about side effects vendors give.

For this study we used two traditionally used species groups "Hercampuri" Gentianella spec. (Gentianaceae) and "Pasuchaca" Geranium spec. (Geraniaceae.), found in the Mercado Aviación in Lima, as small, clearly circumscribed plant group frequently used to treat symptoms of diabetes as a test case to study the taxonomy, indications, dosage, indicated side effects, and additional species used as admixtures and hypothesized that:

1. A wide variety of different species is sold under the same common name, and often several common names exist for one species.

2. There is no consistency in the dosage, or a relationship between dosage and species marketed under the same vernacular name.

3. There is consistency in knowledge on usage and side effects.

\section{Materials and methods \\ Surveys}

Surveys focusing on plants sold under the traditional species concepts "Hercampuri" (Gentianella sp.) and "Pasuchaca" (Geranium sp.) to treat diabetes, as well as species used as additives were conducted at the Mercado Aviación in Lima in December 2012. Researchers would approach the vendors and explain the premise for the study. From those who gave their prior informed consent, information was collected regarding their inventory of "Hercampuri" and "Pasuchaca", as well as of additive species. The vendors were asked about other vernacular names, medicinal indications the plants were used for, dosage, side effects, admixtures to these species, and provenance and seasonality of the material.

\section{Voucher collection}

The specimens are registered under the collection series "RBU," "MRCH," "MONA," "JOG". Vouchers of all specimens were deposited at the National Herbarium of Peru in the Museo de Historia Natural San Marcos (USM). In order to recognize Peru's rights under the Convention on Biological Diversity, especially with regard to the conservation of genetic resources in the framework of a study on medicinal plants, the identification of the plant material was conducted entirely in Peru. No plant material was exported in any form whatsoever.

\section{Species identification and nomenclature}

The nomenclature of plant families, genera, and species follows the Catalogue of the Flowering Plants and Gymnosperms of Peru [54]. The nomenclature was compared to the TROPICOS database (www.tropicos.org). Species were identified using the available volumes of the Flora of Peru [55], as well as [56-58], and reference material in the National Herbarium of Peru (USM). Species and author names for all species encountered are given in Additional file 1.

\section{Results and discussion}

Our surveys in Mercado Aviación in Lima yielded four species of Gentianella sold as "Hercampuri", two of Geranium sold as "Pasuchaca", and three additional species from three genera used as common additives that were sold as anti-diabetic. Gentianella nitida (Grieseb.) Fabris and Gentianella thyrsoidea (Hook.) Fabris were the most commonly sold Gentianaceae, whereas only small samples of Gentianella incurva (Hook.) Fabris and Gentianella tristicha (Gilg.) J.S. Pringle could be found. All these species were sold as "Hercampuri". Interestingly, not a single sample of Gentianella alborosea (Gilg) Fabris, more commonly mentioned in literature as "Hercampuri" was encountered. Geranium sessiliflorum Cav. and Geranium crassipes Hook. ex. Grey were both sold as "Pasuchaca", and again, Geranium dielsianum Kunth., the only species mentioned in the phytomedical literature, was not encountered. Argyrochosma nivea (Poir.) Desv. and Cheilanthes bonariensis (Willd.) Proctor (both Pteridaceae) were interchangeably sold as "Cuti Cuti), and together with Morus $a l b a \mathrm{~L}$. (Moraceae) were used as admixtures in preparations to treat diabetes (Figure 1).

The species used, their indications, and the vernacular names under which they were sold, greatly differed not only from literature on similar markets in other parts of the country, but also from previous studies conducted in Lima (Additional file 1).

Albán [59], Lima, reported Gentianella alborosea (Gilg.) Fabris (Hircampuri, Hercampuri) as used for gastric secretion stimulant, anti-inflammatory (liver), blood purification, Gentianella graminea (H.B.K.) Fabris (Corpus huay, Chinchimali) for the stimulation of bile secretion, anti-inflammatory (liver), and blood purification, Gentianella thyrsoidea (Hook.) Fabris (Huallpa pachaqui, Japachanchara, Tucumia) for the stimulation of bile secretion, anti-inflammatory (liver), anti-diabetic and Morus nigra L. (Mora) as anthelmintic. Brack Egg [60], whole of Peru, mentions Cheilanthes bonariensis (Willd.) Proctor (Cuti Cuti) as febrifuge, Gentiana sedifolia HBK (Hercampure) as aphrodisiac; Gentianella alborosea (Gilg) Fabris (Hercampuri) for diabetes, as diuretic and to lower cholesterol; Gentianella bicolor (Wedd.) Pringle (Corpus huay, Chinchimali), Gentianella thyrsoidea (Hook.) Fabris (Corpus huay, Chinchimali) Geranium dielsianum Kunth (Pasuchaca) as anti-diabetics. Our own previous studies [33,61-70] all from Northern Peru, list Pellaea ternifolia C. Chr. (Cuti Cuti, Cute Cute, Cuticuti, Cute-Cute Amarillo, Cuti Cuti Amarillo) as used for diabetes and liver, 


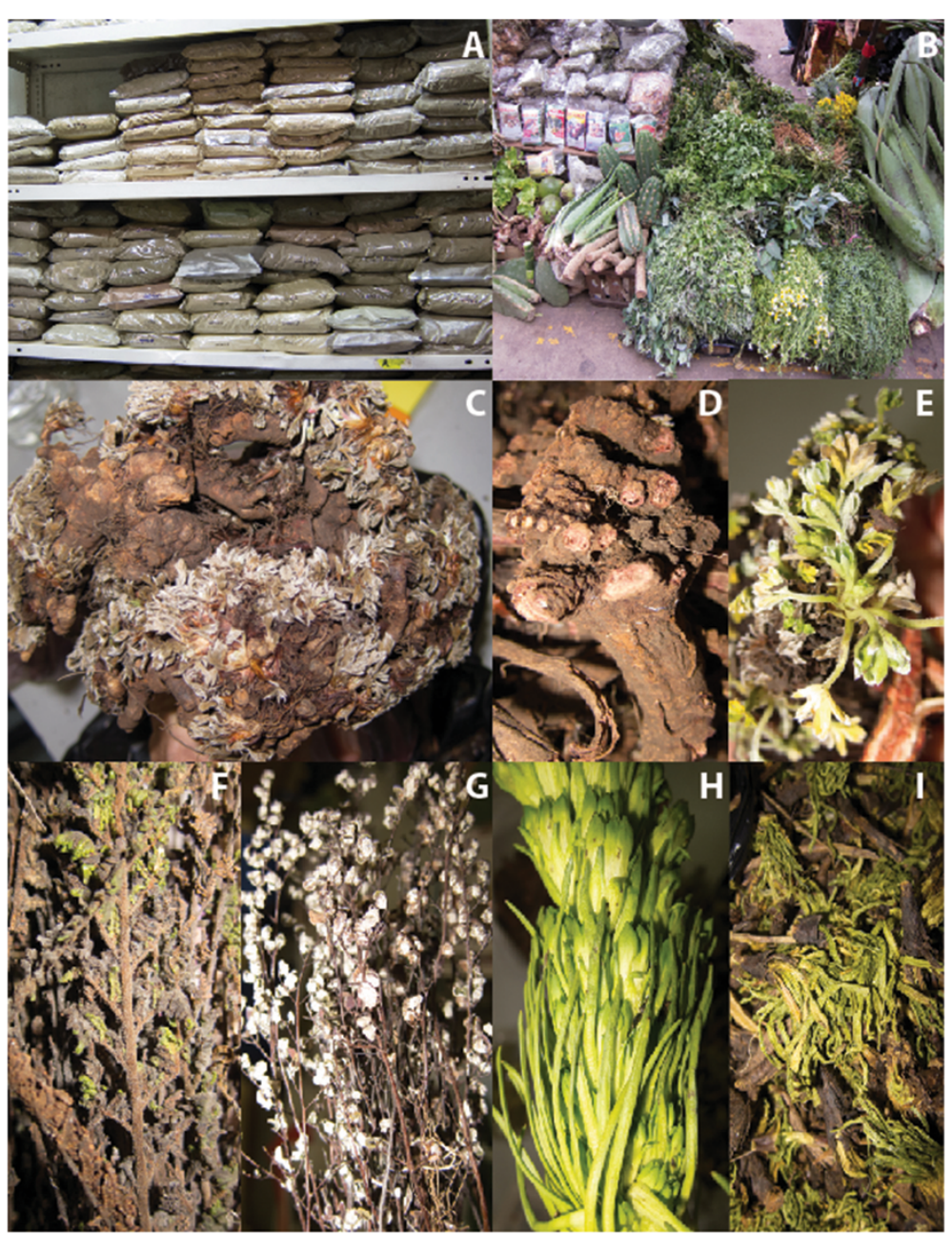

Figure 1 Medicinal plant presentation in Mercado Aviación: A. packaged ground plat material; B. traditional presentation; C-E. Geranium sessiliflorum; D. unidentifiable Geranium fragment; F. Cheilanthes bonariensis; G. Argyrochosma nivea; H. Gentianella thyrsoidea; I. Gentianella nitida.

Gentianella alborosea (Grimes) Pringle (Hercampuri) for diabetes; Gentianella bicolor (Wedd.) J. Pringle (Corpus Way, Corposhuar, Hornamo Leon) for arthritis, diabetes, bone pain, cholesterol, gastritis, liver, blood, rheumatism; Gentianella bruneotincta (Gilg.) J.S. Pringle. (Anga Macha) for Infections of the uterus, after giving birth; Gentianella crassicaulis J.S. Pringle (Violeta Genciana, Hojas de Violeta) for gastritis, "special" diabetes and dizziness; Gentianella dianthoides (H.B.K.) Fabris (Genciana, Egenciana, Amargon, Campanilla) for liver, kidneys, blood, as purgative to loosen the stomach, diabetes, cleansing, blood irrigation, blood problems, liver Infection; Gentianella graminea (H.B.K.) Fabris (Sumaran, Chinchimali, Corpushuay) for diabetes, liver, blood, burn fat, Intestinal fever, cough, fever, infection, allergies of the blood, varicose veins; Geranium ayavacense Willd ex H.B.K., Geranium sessiliflorum Cavanilles (Puli Punchi, Pasuchaca, Pachuchaca, Miscamisca) and Morus alba L. (Morera) for diabetes;
Notholaena nivea (Poir.) Desv. (Doradilla) and Pellaea ternifolia C. Chr. (Cuti Cuti, Cuti Cuti amarillo) against diabetes. All of the Gentianella species were used for psychosomatic disorders [71].

The present study confirms our initial hypothesis that at least in case of Gentianella and Geranium various species are sold under the same common names in Mercado Aviación in Lima, and in other parts of the country. The different fresh Gentianella species are readily identifiable botanically, but neither the collectors nor the vendors do make a direct distinction between species. However, at least half of the surveyed venders in Mercado Aviación sell Gentianella (Hercampuri) in finely powdered form, which makes the morphological identification of the species in the market impossible, and greatly increases the risk for the buyer. In case of Geranium (Pasuchaca) this is slightly less perilous, since none of the species appear to be toxic. However, they 
are mostly sold as dried rhizomes with few leaf fragments, and a morphological identification in the market is difficult even for trained botanists. The best way to ensure correct identification would be DNA bar-coding. The necessary technical infrastructure was however not available locally. The use of DNA bar-coding as quality control tool to verify species composition of samples on a large scale would require to carefully sample every batch of plant material sold in the market. The volatility of the markets make this is an impossible logistical task. We also confirmed that all of the species encountered, and the same or closely related species mentioned in literature sell under wide variety of common names. Worse, one species might be sold e.g. as "Hercampuri" in one location or market stand, while selling under a different name at a neighboring stand. As expected we did not find any consistency in the dosage of "Hercampuri" (ranging from 20-50 g/preparation) in Mercado Aviación, nor in the maximum number of days the preparation was to be taken (unlimited to a maximum of 15), nor in vendors agreeing on possible side effects. This is the more perilous as this stretched across species, i.e. Gentianella thyrsoidea, which clearly has toxic compounds, was often classified as benign, while other species of Gentianella were sold with clear warnings and vise versa. In case of "Pasuchaca" dosages were much more consistent, while the fern admixtures again varied wildly in dosage. The same holds true when comparing dosages with the use of the same or similar species mentioned in literature (Additional file 1). We also confirmed that the vendors in general knew what a plant was used for, that the material had to be boiled as tea, and which other ethnospecies were supposed to be included in a preparation, however, as indicated above, knowledge about side effects was sketchy.

Information on the possible efficacy of all the species researched is scarce. Karato et al. [72] report on some glucosidase inhibition in Geranium dielsianum, which might explain the use of Geranium in diabetes. However, Geranium dielsianum was hardly sold in Mercado Aviación. Some phytochemical analysis has been done on Gentianella alborosea [73], and the plant was shown to have free radical scavenging properties [74]. However, Gentianella alborosea again was not common in the market. Gentianella nitida has been a little better studies from a phytochemical perspective [75-77] and is also known for its antimicrobial and free radical scavenging activity [78]. None of these studies however confirm efficacy as anti-diabetic. Even worse, the botanical information of the species mentioned above is not free of doubt.

The only species in anti-diabetic mixtures encountered that actually has proven activity is the introduced Morus alba [79-93] This species is well known in Chinese Traditional Medicine, and also used other pharmacopoeiae, e.g. [94].
These results indicate that even in case of only a few plant species, used for a very clearly circumscribed application, patients run a considerable risk when purchasing their remedies in the market. The possible side effects in this case are the more serious because diabetes has to be treated long term, and as such the patients are ingesting possible toxic remedies over a long period of time. Much more control, and a much more stringent identification of the material sold in public markets, and entering the global supply chain via Internet sales, would be needed.

\section{Additional file}

Additional file 1: Medicinal species found in the present study compared to literature.

\section{Competing interest}

The authors declare that they have no competing interest.

\section{Authors' contributions}

All authors participated in the fieldwork and literature research for this study. RB and NPZ analyzed the data and prepared the manuscript. All authors provided revisions to the manuscript. All authors read and approved the final manuscript.

\section{Acknowledgements}

We gratefully thank the vendors in Mercado Aviación for their cooperation, and the Herbario Nacional de Peru at Museo de Historia Natural San Marcos, and in particular it's Director Dr. Betty Millán for untiring support.

\section{Author details}

${ }^{1}$ William L. Brown Center, Missouri Botanical Garden, PO Box 299, Saint Louis, MO 63166-0299, USA. ${ }^{2}$ Herbario Nacional de Bolivia, Instituto de Ecología-UMSA, Campus Universitario, Cota Cota Calle 27, Apdo. correo central, La Paz, Postal 10077, Bolivia. ${ }^{3}$ Museo de Historia Natural-UNMSM, Av Arenales 1256 Jesús María, Lima, Perú. ${ }^{4}$ UEES (Universidad de Especialidades Espiritu Santo), Km 2.5 via Samborondon, Guayas, Ecuador. ${ }^{5}$ Ministerio del Interior-Sanidad Policia Nacional, Hospital Geriatrico. Jr. Ramon Castilla Cuadra 5, Distrito de San Miguel, Lima, Perú. ${ }^{6} \mathrm{CIBN}$, Facultad de Medicina San Fernando-UNMSM, Av Grau 755, Lima, Perú.

Received: 3 April 2013 Accepted: 24 May 2013

Published: 30 May 2013

\section{References}

1. Camino L: Cerros, plantas y lagunas poderosas: La medicina al norte del Perú. Lima: Lluvia Editores; 1992.

2. Sharon D: Shamanismo y el Cacto Sagrado-Shamanism and the Sacred Cactus. San Diego, Museum of Man: San Diego Museum Papers 37; 2000.

3. Cruz Sánchez G: Informe sobre las aplicaciones populares de la cimora en el norte del Perú. Rev Farmacol Medic Experiment Lima 1948, 1:253-258.

4. Cardenas M, De Rios Dobkin M: Plant hallucinogen, shamanism and Nazca ceramics. J Ethnopharm 1980, 2:233-246.

5. De Rios Dobkin M: Folk curing with a psychedelic cactus in North Coast Peru. International J Soc Psych 1969, 15:23-32.

6. De Rios Dobkin M: Plant hallucinogens and the religion of the Mochica, an ancient Peruvian people. Econ Bot 1977, 31:189-203.

7. De Rios Dobkin M: Trichocereus pachanoi: a mescaline cactus used in folk healing uses in Peru. Econ Bot 1968, 22:191-194.

8. Bristol ML: Tree Datura drugs of the Columbian Sibundoy. Bot Mus Leafl 1969, 22:165-227.

9. Martin RT: The role of coca in the history, religion, and medicine of South American Indians. Economic Botany 1970, 24:422-438.

10. Naranjo P: Social function of coca in pre-Columbian America. J Ethnopharm 1981, 3:161-172. 
11. Plowman T: Amazonian coca. J Ethnopharm 1981, 3:195-225.

12. Plowman T: The ethnobotany of coca (Erythroxylum spp. Erythroxylaceae). Adv Econ Bot 1984, 1:62-111.

13. Plowman T: The origin, evolution, and diffusion of coca, Erythroxylum spp. in South and Central America. Pap Peabody Mus Arch Ethn 1984 76:125-163.

14. Rivier L, Lindgren JE: Ayahuasca, the South American Hallucinogenic drink: an ethno botanical and chemical investigation. Econ Bot 1972, 26:101-129.

15. Schultes RE, Raffauf R: Vine of the Soul. Oracle, Arizona: Synergetic Press; 1992.

16. Bianchi A, Samorini G: Plants in Associacion with Ayahasuca. Jahrb Ethnomed 1993, 2:21-42.

17. Chiappe M, Lemlij M, Millones L: Alucinogenos y Shamanismo en el Peru contemporaneo. Lima: El Virrey; 1985.

18. Larco-Herrera F: Plantas que curan y plantas que matan de la Flora del Cusco. Rev Mus Nac, Lima 1940, IX(1):74-127.

19. De Ferreyra EC: Plantas medicinales alto-andinas. Bol Colon Suiza Peru 1978, 1:1-6.

20. De Ferreyra EC: Plantas que curan las heridas del hombre y los animales. Bol Lima 1981, 10:1-12

21. Lira JA: Medicina Andina Farmacopea y rituales. Cusco: Centro Bartolome de las Casas; 1985

22. Franquemont C, Plowman T, Franquemont E, Niezgoda C, King S, Sperling C, Davis W: The Ethnobotany of Chinchero, an Andean Community in Southern Peru. Field Bot $n$ ser 1990, 24.

23. Girault L, Kallawaya: Curanderos itinerantes de los Andes. UNICEF-OPS-OMS: La Paz; 1987

24. Bastien J: Drum and Stethoscope, Integrating Ethnomedicine and Biomedicine in Bolivia. Salt Lake City: University of Utah Press; 1992.

25. Bastien J: Healers of the Andes: Kallawaya Herbalists and Their Medicinal Plants. Salt Lake City: University of Utah Press; 1987.

26. Roersch C: Plantas Medicinales en el Sur Andino del Perú. Königstein: Koeltz Scientific Books; 1994.

27. Prance GT: Ethnobotanical notes from Amazonian Brazil. Econ Bot 1972, 26:221-233.

28. Rutter RA: Catálogo de plantas útiles de la Amazonía Peruana. Com Cult Peru 1990, 22:1-349.

29. Duke J, Vázquez J: Amazonian Ethnobotanical Dictionary. Boca Raton: CRC Press; 1994.

30. Polia M: Las Lagunas de los Encantos-Medicina Tradicional Andina en el Peru septentrional. CePeSer: Lima; 1988

31. De Feo V: Ethnomedicinal field study in northern Peruvian Andes with particular reference to divination practices. J Ethnopharm 2003, 85:243-256.

32. De Feo V: Medicinal and magical plants on northern Peruvian Andes. Fitoterapia 1992, 63:417-440.

33. Bussmann RW, Sharon D: Traditional plant use in Northern Peru: Tracking two thousand years of health culture. J Ethnobiol Ethnomed 2006, 2:47

34. Bussmann RW, Sharon D, Vandebroek I, Jones A, Revene Z: Health for sale: The medicinal plant markets in Trujillo and Chiclayo, Northern Peru. J Ethnobiol Ethnomed 2007, 3:37.

35. Sharon D, Bussmann RW: Avances de la etnobotánica en Trujillo, Peru: El programa MHIRT. Arnaldoa 2006, 13(2):398-406.

36. Sharon D, Bussmann RW: Plantas Medicinales en la Obra del Obispo Don Baltasar Jaime Martínez Compagñon (Siglo XVIII). In Desde el exterior: El Peru y sus estudios. Edited by Millones L, Kato T. Nagoya, UNMSM: Tercer Congreso Internacional de Peruanistas; 2006:147-165.

37. Revene Z, Bussmann RW, Sharon D: From Sierra to Coast: Tracing the Supply of Medicinal Plants in Northern Peru-a plant collector's tale. Ethnobot Res Appl 2008, 6:15-22.

38. Bussmann RW, Glenn A, Meyer K, Rothrock A, Townesmith A: Herbal mixtures in traditional medicine in Northern Peru. J Ethnobiol Ethnomed 2010, 6(10):1-11.

39. Bussmann RW, Sharon D, Ly J: From garden to market? The cultivation of native and introduced medicinal plant species in Cajamarca, Peru and implications habitat conservation. Ethnobota Res App/ 2008 , 6:351-361

40. Bussmann RW, Sharon D, et al: From collection to market and cure-an interdisciplinary study of traditional plant use in Northern Peru. In Recent Developments and Case Studies in Ethnobotany. Recife, Brazil: Brazilian Society of Ethnobiology and Ethnoecology (SBEE) Publication Group of Ecology and Applied Ethnobotany (NUPEEA): 2010:184-207.
41. Bussmann RW, Sharon D: Markets, Healers, Vendors, Collectors, -the sustainability of medicinal plant use in Northern Peru. Mt Res Dev 2009, 29(2): 128-134.

42. Bussmann RW, Sharon D, Lopez A: Blending Traditional and Western Medicine: Medicinal plant use amongst patients at Clinica Anticona in El Porvenir, Peru. Ethnobot Res Appl 2007, 5:185-199.

43. Bussmann RW, Sharon D, Garcia M: From Chamomile to Aspirin? Medicinal Plant use among clients at Laboratorios Beal in Trujillo, Peru. Ethnobot Res Appl 2009, 7:399-407.

44. International Diabetes Foundation: Diabetes prevalence-Country ranking : 2010. [http://www.allcountries.org/ranks/ diabetes_prevalence_country_ranks.html.html] Accessed 05/23/2013.

45. Hammond GB, Fernández ID, Villegas L, Vaisbeerg AJ: A survey of traditional medicinal plants from the Callejón de Huaylas, Department of Ancash, Perú. J Ethnopharm 1998, 61:17-30.

46. Bussmann RW, Barocio Y, Díaz PD, Sharon D: Peruvian Plants Canchalagua (Schkuhria pinnata (Lam.) Kuntze), Hercampuri (Gentianella alborosea (Gilg.) Fabris), and Corpus Way (Gentianella bicolor (Wedd.) J. Pringle) prove to be effective in the treatment of acne. Arnaldoa 2008, 15(1):149-152

47. Bussmann RW, Glenn A, Sharon D, Chait G, Díaz D, Pourmand K, Jonat B, Somogy S, Guardado G, Aguirre C, Meyer K, Rothrock A, Townesmith A: Antibacterial activity of Northern Peruvian medicinal plants. Ethnobot Res App/ 2011, 9:67-96.

48. Bussmann RW, Glenn A, Sharon D: Antibacterial activity of medicinal plants of Northern Peru-can traditional applications provide leads for modern science? Ind J Trad Med 2010, 9(4):742-753.

49. Bussmann RW, Malca G, Glenn A, Sharon D, Chait G, Díaz D, Pourmand K, Jonat B, Somogy S, Guardado G, Aguirre C, Meyer K, Rothrock A, Townesmith A, Effio-Carbajal J, Frías-Fernandez F, Benito M: Minimum inhibitory concentration of medicinal plants used in Northern Peru as antibacterial remedies. J Ethnopharm 2010, 132:101-108.

50. Bussmann RW, Sharon D, Castro M, Cardenas R, Chait G, Regalado S, Del Toro CR, Malca GG, Perez AF, Glenn A: Phyto-Chemical Analysis of Peruvian Medicinal Plants. Arnaldoa 2009, 16(1):105-110.

51. Bussmann RW, Sharon D, Diaz D, Cardenas R, Chait G, Castro M, Regalado S, Del Toro CR, Malca GG, Perez AF, Glenn A: Antibacterial activity of medicinal plant species in Northern Peru. Arnaldoa 2009, 16(1):93-103.

52. Bussmann RW, Sharon D, Perez F, Díaz D, Ford T, Rasheed T, Silva R: Antibacterial activity of Northern-Peruvian Medicinal Plants-a low cost laboratory approach to assess biological activity. Arnaldoa 2008, 15(1):127-148.

53. Bussmann RW, Malca G, Glenn A, Sharon D, Nilsen B, Parris B, Dubose D, Ruiz D, Saleda J, Martinez M, Carillo L, Walker K, Kuhlman A, Townesmith A: Toxicity of medicinal plants used in Northern Peru. J Ethnopharm 2011, 137:121-140.

54. Brako L, Zarucchi JL (Eds): Catalogue of the Flowering Plants and Gymnosperms of Peru. Saint Louis, MO: Missouri Botanical Garden; 1993.

55. McBride JF (Ed): Flora of Peru. Fieldiana Botany. Chicago: Field Museum of Natural History. 1936-1981.

56. Ulloa Ulloa C, Jørgensen PM: Arboles y arbustos de los Andes del Ecuador. AAU Rep 1993, 30:1-263.

57. Jørgensen PM, Ulloa Ulloa C: Seed plants of the High Andes of Ecuadora checklist. AAU Rep 1994, 34:1-443.

58. Pestalozzi HU: Flora ilustrada altoandina. Cochabamba: Herbario Nacional de Bolivia and Herbario Forestal Nacional Martin Cardenas; 1998

59. Albán J: Plantas medicinales usadas en Lima para los transtornos digestivos. UNMSM, EAP Ciencias Biológicas, Lima: Tesis título profesional de Biólogo; 1984

60. Brack Egg A: Dictionario enciclopedico de plantas utiles del Peru. Cusco: CBC; 1999 .

61. Bussmann RW, Glenn A: Fighting infections-medicinal plants used in Northern Peru for the treatment of bacterial and fungal infections and inflammation symptoms. J Med PI Res 2011, 5(8):1297-1304.

62. Bussmann RW, Glenn A: Mending the heart. Plants used in Peruvian ethnomedicine for heart disease, blood pressure irregularities and cholesterol control. Arnaldoa 2011, 18(1):1-9.

63. Bussmann RW, Glenn A: Peruvian medicinal plants for the treatment of liver and gallbladder ailments. Arnaldoa 2010, 17(2):243-253.

64. Bussmann RW, Glenn A: Plants used for the treatment of gastro-intestinal ailments in Northern Peruvian ethnomedicine. Arnaldoa 2010, 17(2):255-270. 
65. Bussmann RW, Glenn A: Traditional knowledge for modern ailmentsplants used for the treatment of diabetes and cancer in Northern Peru. J Med PI Res 2011, 5(31):6916-6930.

66. Bussmann RW, Glenn A: Medicinal plants used in Northern Peru for reproductive problems and female health. J Ethnobiol Ethnomed 2010, 6(30)

67. Bussmann RW, Glenn A: Cooling the heat-Traditional remedies for malaria and fever in Northern Peru. Ethnobot Res Appl 2010, 8:125-134.

68. Bussmann RW, Glenn A: Fighting pain. Traditional Peruvian remedies for the treatment of Asthma, Rheumatism, Arthritis and sore bones. Ind J Trad Kno 2011, 10(3):397-412.

69. Bussmann RW, Glenn A: Traditional medicinal plants used in Northern Peru for kidney problems and urinary infections. Arnaldoa 2011, 18(2):1-10.

70. Bussmann RW, Glenn A: Traditional Peruvian medicine for the treatment of respiratory disorders. Rev Per Biol 2010, 17(2):331-346.

71. Bussmann RW, Sharon D, Glenn A: Healing the body, healing the soul. Traditional remedies for "magical" ailments, nervous system and psychosomatic disorders in Northern Peru. Afr. J Pharm Pharmacol 2010, 4(9):580-629.

72. Karato M, Yamaguchi K, Takei S, Kino T, Yazawa K: Inhibitory effects of pasuchaca (Geranium dielsianum) extract on alpha-glucosidase in mouse. Biosci Biotech Biochem 2006, 70(6):1482-1484.

73. Kawahara N, Masuda K, Sekita S, Satake M: A new secoiridoid glucoside, amaronitidin, from Peruvian folk medicine "Hercampuri" (Gentianella nitida). Chem Pharm Bull (Tokyo) 2001, 49(6):771-772.

74. Acero N, Linares F, Gálan de Mera A, Oltra B, Muñoz-Mingarro D: Apoptotic and free radical scavenging properties of the methanolic extract of Gentianella alborosea. Fitoterapia 2006, 77(6):475-477.

75. Lacaille-Dubois MA, Galle K, Wagner H: Secoiridoids and xanthones from Gentianella nitida. Plant Med 1996, 62(4):365-368.

76. Kawahara N, Nozawa M, Flores D, Bonilla P, Sekita S, Satake M: Sesterpenoid from Gentianella alborosea. Phytochemy 2000, 53(8):881-884.

77. Kawahara N, Nozawa M, Kuruta A, Hakamatsuka T, Sekita S, Satake M: A novel sesquiterpenoid, nitol, as a potent enhancer of IL-2 gene expression in a human T cell line, from the Peruvian folk medicine "Hercampuri" (Gentianella nitida). Chem Pharm Bull (Tokyo) 1999, 47(9):1344-1345.

78. Rojas R, Doroteo V, Bustamante B, Bauer J, Lock O: Antimicrobial and free radical scavenging activity of Gentianella nitida. Fitoterapia 2004, 75(7):754-757.

79. Lemus I, García R, Delvillar E, Knop G: Hypoglycaemic activity of four plants used in Chilean popular medicine. Phytother Res 1999, 13(2):91-94.

80. Hussain Z, Waheed A, Qureshi RA, Burdi DK, Verspohl EJ, Khan N, Hasan M: The effect of medicinal plants of Islamabad and Murree region of Pakistan on insulin secretion from INS-1 cells. Phytother Res 2004, 18(1):73-77.

81. Singab AN, El-Beshbishy HA, Yonekawa M, Nomura T, Fukai T: Hypoglycemic effect of Egyptian Morus alba root bark extract: effect on diabetes and lipid peroxidation of streptozotocin-induced diabetic rats. J Ethnopharm 2005, 100(3):333-338.

82. Hansawasdi C, Kawabata J: Alpha-glucosidase inhibitory effect of mulberry (Morus alba) leaves on Caco-2. Fitoterapia 2006, 7-8:568-573.

83. Arýkan D, Sívríkaya SK, Olgun N: Complementary alternative medicine use in children with type 1 diabetes mellitus in Erzurum, Turkey. J Clinl Nurs 2009, 18(15):2136-2144.

84. Naowaboot J, Pannangpetch P, Kukongviriyapan V, Kukongviriyapan U, Nakmareong S, Itharat A: Mulberry leaf extract restores arterial pressure in streptozotocin-induced chronic diabetic rats. Nutr Res 2009, 29(8):602-608.

85. Zhang $M$, Chen M, Zhang HQ, Sun S, Xia B, Wu FH: In vivo hypoglycemic effects of phenolics from the root bark of Morus alba. Fitoterapia 2009, 80(8):475-477

86. Benalla W, Bellahcen S, Bnouham M: Antidiabetic medicinal plants as a source of alpha glucosidase inhibitors. Curr Diab Rev 2010, 6(4):247-254.

87. Duangjai A, Ingkaninan K, Limpeanchob N: Potential mechanisms of hypocholesterolaemic effect of Thai spices/dietary extracts. Nat Prod Res 2011, 25(4):341-352.

88. El-Sayyad HI, El-Sherbiny MA, Sobh MA, Abou-El-Naga AM, Ibrahim MA, Mousa SA: Protective effects of Morus alba leaves extract on ocular functions of pups from diabetic and hypercholesterolemic mother rats. Int J Bio Sci 2011, 7(6):715-728.

89. Kim GN, Kwon Yl, Jang HD: Mulberry leaf extract reduces postprandial hyperglycemia with few side effects by inhibiting a-glucosidase in normal rats. J Med Food 2011, 14(7-8):712-717.
90. Hunyadi A, Martins A, Hsieh TJ, Seres A, Zupkó I: Chlorogenic acid and rutin play a major role in the in vivo anti-diabetic activity of Morus alba leaf extract on type II diabetic rats. PLoS One 2012, 7(11):e50619.

91. Hunyadi A, Veres K, Danko B, Kele Z, Weber E, Hetenyi A, Zupko I, Hsieh T: In vitro Anti-diabetic Activity and Chemical Characterization of an Apolar Fraction of Morus alba Leaf Water Extract. Phytother Res 2012, 26(12). doi: 10.1002/ptr.4803.

92. Naowaboot J, Pannangpetch $\mathrm{P}$, Kukongviriyapan V, Prawan A Kukongviriyapan $U$, Itharat A: Mulberry leaf extract stimulates glucose uptake and GLUT4 translocation in rat adipocytes. Amn J Chin Med 2012, 40(1):163-175

93. Wang $\mathrm{HJ}$, Chiang $\mathrm{BH}$ : Anti-diabetic effect of a traditional Chinese medicine formula. Food Funct 2012, 3(11):1161-1169.

94. Lans CA: Ethnomedicines used in Trinidad and Tobago for urinary problems and diabetes mellitus. J Ethnobiol Ethnomed 2006, 2:45.

doi:10.1186/1746-4269-9-37

Cite this article as: Bussmann et al.: Peril in the market-classification and dosage of species used as anti-diabetics in Lima, Peru. Journal of Ethnobiology and Ethnomedicine 2013 9:37.

\section{Submit your next manuscript to BioMed Central and take full advantage of:}

- Convenient online submission

- Thorough peer review

- No space constraints or color figure charges

- Immediate publication on acceptance

- Inclusion in PubMed, CAS, Scopus and Google Scholar

- Research which is freely available for redistribution 